\title{
VIRAL AND FUNGAL DISEASES OF WHEAT IN UKRAINE: A THREAT TO FOOD SECURITY
}

\section{Mishchenko L. T., Dunich A. A.}

\section{INTRODUCTION}

Monitoring and control of plant pathogens are of strategic importance for the bio- and food state security, sustainable production of plant products for human and animal food, and for its export ${ }^{1}$. Underestimation and lack of knowledge about viruses, as well as the emergence of their new variants is very dangerous and can lead to a global economic crisis and unpredictable consequences. Plant viruses should also not be underestimated, as they are a significant economic factor and cause a significant reduction in crop yields (15-100\%, on average $-30-40 \%)^{2}$. Moreover, against the background of climate change, that further increases the losses in the agro-industrial sector ${ }^{3}$. Unlike human and animal viruses, for which drugs and vaccines can be made, working and learning remotely, viral and fungal plant diseases pose a threat to food security because there are no effective protection methods for them.

Soil and climatic conditions of Ukraine allow high yields of grain crops. Today, pathogens are currently one of the major threats to our food security. At least $10 \%$ of global food production is lost as a consequence of plant diseases, which amounts to the economic value of US $\$ 220$ billion annually ${ }^{4}$. Furthermore, the global climate change exacerbates the impact of the diseases. Moreover, our previous studies show that viral isolates circulating in Ukraine have a high epidemic

${ }^{1}$ Fones H.N., Bebber D.P., Chaloner T.M. et al. Threats to global food security from emerging fungal and oomycete crop pathogens. Nat Food. 2020. 1. P. 332-342.

2 Jones R.A.C. Global plant virus disease pandemics and epidemics. Plants. 2021. 10(2). 233

${ }^{3}$ Priyadi M., Upadhyay P. Emerging plant diseases under changing climate scenario. In: Singh K.P., Jahagirdar S., Sarma B.K. (eds) Emerging trends in plant pathology. Springer, Singapore. 2021. P. 19-31

${ }^{4}$ Strange R.N., Scott P.R. Plant disease: a threat to global food security. Annual Review of Phytopathology. 2005. 43(3). P. 83-116. 
potential and pathogenicity, as they lead not only to reduced crop yields, but also to a significant deterioration in product quality.

Wheat is one of the important crops for Ukrainian agriculture (it occupies an area of over 6 million hectares annually). Wheat streak mosaic virus (WSMV) is the causative agent of one of the main and most common viral diseases of wheat ${ }^{5}$. WSMV causes a lag in plant growth (10\%), a decrease in spike productivity per plant (by 38\%), spike shortening (by 38\%), a decrease in the number and size of seeds (by $50 \%)^{6,7}$. Barley/cereal yellow dwarf viruses (YDVs) cause yellow dwarf disease (YDD), which is a continuous risk to cereals including wheat production worldwide. These viruses cause leaf yellowing and stunting, resulting in yield reductions of up to $80 \%$. One of the first causal agents of YDD in wheat is barley yellow dwarf virus (BYDV) ${ }^{8}$. In wheat plants, YDD symptoms consist of leaf yellowing or reddening often most visible on the flag leaf, stiff leaves with an upright posture, diminished root growth, and plant stunting. Heading is delayed; fewer grains form and these are shriveled. Wheat grain yields are diminished by $60 \%-84 \%$ and seed quality is greatly impaired ${ }^{9}$.

Pathogens of fungal etiology also cause significant damage. The results of research show that agrocenoses of winter wheat are most affected by root rot, powdery mildew, brown and stem rust, various leaf spots, leaf septoria, snow mold, Pyrenophora and Alternaria ${ }^{10}$. Their prevalence can reach $75-100 \%$, which poses environmental risks

${ }^{5}$ Singh K., Wegulo S.N., Skoracka A., Kundu J.K. Wheat streak mosaic virus: A century old virus with rising importance worldwide. Mol. Plant Pathol. 2018. 19. P. 2193-2206.

${ }^{6}$ Mishchenko L.T. Viral diseases of winter wheat. K.: Phytosociocenter. 2009. 352 p. (in Ukrainian)

Mishchenko L.T., Dunich A.A., Budzanivska I.G., Mishchenko I.A. Viral infections of winter wheat and soybean and their influence on crop yield under climate change conditions. Bulletin of Taras Shevchenko National University of Kyiv. Series: Biology. 2018a. Vol. 75(1). P. 11-21. (in Ukrainian)

${ }^{8}$ Namara L.M., Gauthier K., Walsh L., Thébaud G., Gaffney M., Jacquot E. Management of yellow dwarf disease in Europe in a post-neonicotinoid agriculture. Pest Management Science. 2020. 76(7). P.2276-2285.

${ }^{9}$ Nancarrow N., Aftab M., Hollaway G., Rodoni B., Trębicki P. Yield losses caused by barley yellow dwarf virus-PAV infection in wheat and barley: a three-year field study in South-Eastern Australia. Microorganisms. 2021. 3(9). P. 645.

${ }^{10}$ Miedaner, T., Juroszek, P. Climate change will influence disease resistance breeding in wheat in Northwestern Europe. Theor Appl Genet. 2021. 
associated with the epiphytic development of diseases and the further increase of biological and chemical pollution in agroecosystems ${ }^{11}$.

The yield losses due to pathogens can be reduced through efficient management of diseases in the cropping systems. However, the efficacy of the management approaches depends on early diagnostics. One of the main bottlenecks in the diagnosis of, for example, plant viruses is that the symptoms appear only in the later stages of the disease. As infected plants cannot be cured, viral diseases are most effectively managed prior to infection or during early stages of the disease. So, success of the early disease detection is determined by the ability to identify diseased plants $^{12}$. Viral disease diagnostics by symptoms is more challenging than in case of fungal or bacterial pathogens. The lack of a reliable method of diagnosis in the early stages of pathogenesis complicates protection against diseases in agricultural systems and prevents the detection of genetic markers for the selection of the best varieties. So, it is very important to monitor the disease symptoms which may change over the years due to different climatic conditions, new plant varieties and altered properties of pathogens.

\section{Viral diseases}

During long-term monitoring studies (for more than 30 years) of winter wheat affected with viral diseases we found that wheat in Ukraine is infected with six viruses: wheat streak mosaic virus (WSMV), winter wheat Russian mosaic virus (WWRMV), barley yellow mosaic virus (BYDV), brome streak mosaic virus (BStMV), brome mosaic virus (BMV), barley stripe mosaic virus (BSMV). The WSMV isolate from Poltava region has been studied in detail ${ }^{6}$. Since 2011, WSMV and BYDV-PAV are the main viruses circulating in the Kyiv, Poltava and Kharkiv regions. Symptoms of the most common and investigated WSMV and BYDV-PAV are presented (Fig.1, 2).

${ }^{11}$ Różewicz M., Wyzińska M., Grabiński J. The most important fungal diseases of cereals-problems and possible solutions. Agronomy. 2021. 11(4). P.714.

12 Jeong J., Ju H., Noh J. A review of detection methods for the plant viruses. Res. Plant Dis. 2014. 20(3). P. 173 -181. 


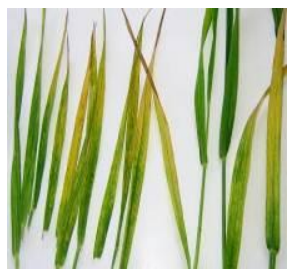

A

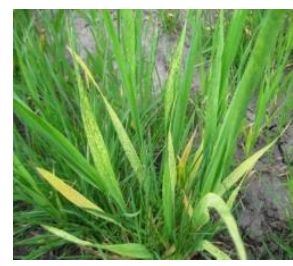

B

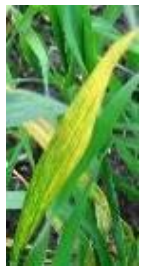

$\mathrm{C}$

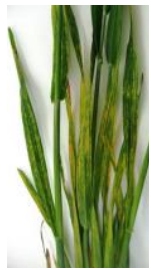

$\mathrm{D}$

Fig. 1. WSMV induced symptoms on wheat plants: A - var. Donskaya polukarlikovaya, 2001; B - WSMV-infection, B - Smuhlianka, Poltava region, 2013; C - var. Ukrainka poltavska, 2008; D - var. Julia, Chernihiv region, 2019

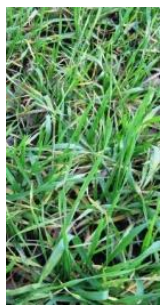

A

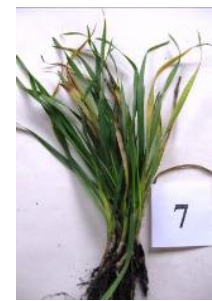

B

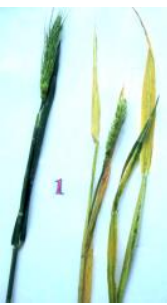

$\mathrm{C}$

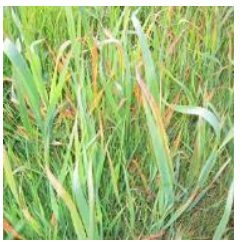

$\mathrm{D}$

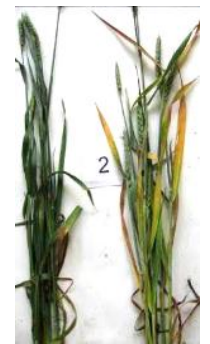

$\mathrm{E}$

Fig. 2. Symptoms caused by BYDV-PAV: autumn tillering, 2012, A - wheat var. Bogdana, Poltava region and B - D-7, Kyiv region; C - wheat var. Antonivka, Mykolaiv region, 2013; D - oat var. Skakun, 2008; E - wheat var. Russia, Poltava region, 2012

Long-term monitoring of wheat fields (2011-2017) and results of virus detection by serological and molecular methods revealed that BYDV and WSMV were replacing each other from year to year, and cases of co-infection of these viruses were not recorded (Fig. 3). 


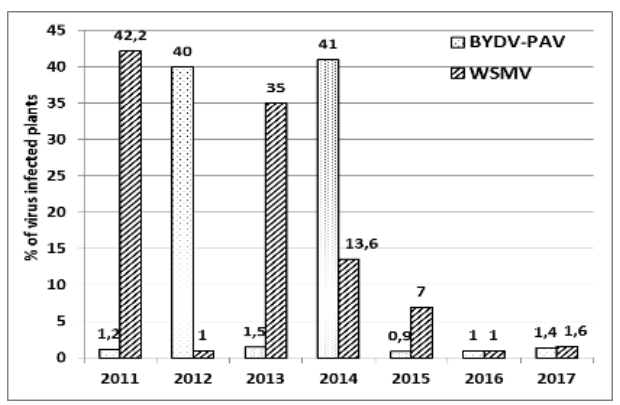

A

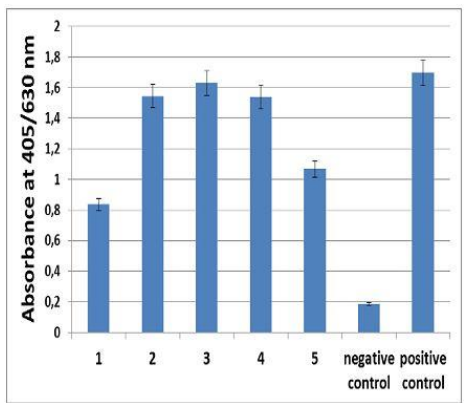

B

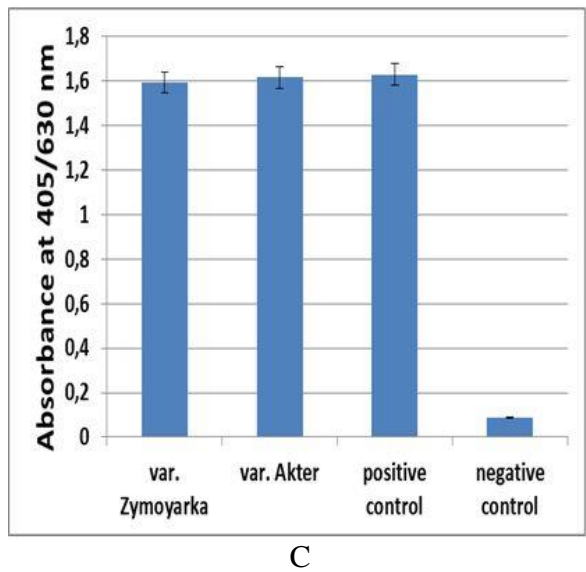

Fig. 3. DAS-ELISA analysis of wheat plants for the presence of WSMV and BYDV-PAV: A - 2011-2017; $B-2019 ; C-2020$

In 2011-2017, it was revealed that BYDV and WSMV are replacing each other from year to year, and cases of co-infection of these viruses are not recorded. In 2011, 2013 and 2015 WSMV prevailed in the inspected regions (Kyiv, Poltava, Kharkiv), and BYDV was detected only in $1.2 \%, 1.5 \%$, and $0.9 \%$ of all plants with viral symptoms, respectively. In contrast, in 2012 and 2014 the frequency of BYDV detection was significantly higher than WSMV (40-41\% and 1-13.6\%, respectively). ELISA data were confirmed by transmission electron microscopy (TEM) and reverse transcription polymerase chain reaction (RT-PCR) (Fig. 4, 5). 


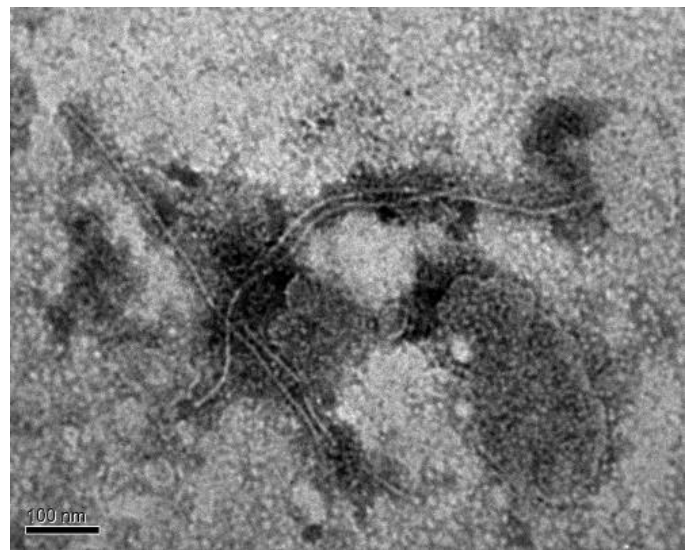

Fig. 4. TEM picture of WSMV virions

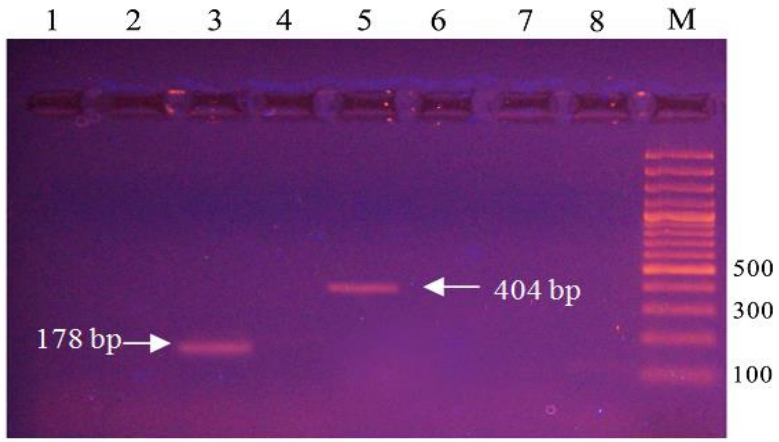

Fig. 5. Gel electrophoresis of PCR fragments from WSMV (404 bp) and BYDV (178 bp) for the $C P$ gene (lane 1, 8 -negative controls; lane M - DNA marker)

The analysis of the dependence of circulation of the viruses in the agrocenoses on weather conditions change was carried out. It has been established that the periodic variability of viruses (WSMV or BYDV) is closely related to agroclimatic changes (air temperature, rainfall, temperature at soil surface, soil temperature on tillering node depth of winter crops and perennial grasses, and soil freezing depth in winter) that affect their host plants, vectors throughout the year and plants reservoirs in the winter, and also cause symptoms similar to viral infection. A decrease in viral infection of wheat and a more stable gross harvest of grain and yield in recent years is substantiated. This is due to the 
development of new wheat cultivars, adapted to negative biotic/abiotic factors and shift of sowing dates to later ones. It has been experimentally proved that the Poltava isolate of WSMV is not seed-transmitted. Even if contamination of seeds with WSMV is possible, the frequency of such cases is insignificant and, as we think, does not play an important role in the epidemiology of this wheat virus in Ukraine ${ }^{13}$.

In 2018, winter wheat plants var. Malynivka (the isolate named as Ukraine-Mal-18, Ac. No in NCBI GenBank is MH523356) and var. Epokha Odeska (isolate Ukraine-Ep-18, Ac. No MH523357) with WSMV-like mild and severe streak symptoms were found near Kharkiv in the eastern part of Ukraine. DAS-ELISA and RT-PCR showed that both wheat samples were infected with WSMV. BYDV-PAV antigens were not detected. These two samples were taken for the phylogenetic analysis. In our study, we revealed that the Ukrainian WSMV isolates are clustered into the clade B or WSMV- $\Delta \mathrm{E}$ (Fig. 6). The Ukrainian isolates, like other isolates of the $\mathrm{B}$ and $\mathrm{B} 1$ clades, have a triplet deletion at the position 8412-8414 nt in the $C P$ gene sequence, which led to the absence of the amino acid Glycine. Analysis showed that the Ukrainian WSMV isolates have the highest percentage of identity with all wheat European isolates from the clade B. Isolate Ukraine-Mal-18 has the highest level of the sequence identity (93.5-95.9\% nt and $93.6-95.0 \%$ aa) with the clade B isolates. The isolate Ukraine-Ep-18 shares identity of $89.2-91.4 \%$ (nt) and $88.6-87.1 \%$ (aa) with the clade B isolates. Noteworthy, the UkraineEp-18 and Ukraine-Mal-18 isolates are the most divergent among the WSMV- $\Delta \mathrm{E}$ isolates based on amino acid $\mathrm{CP}$ sequence. A comparative analysis of aa sequences of Ukrainian isolates and isolates from clades B and B1 revealed significant differences. Thus, the Ukrainian isolate Ukraine-Mal-18 has 12 aa substitutions in the studied region of the $\mathrm{CP}$ gene and Ukraine-Ep-18 has 25 aa substitutions, while all other isolates of group B have 0 to 2 aa substitutions (Fig. 7). Besides, it was shown that the Ukrainian wheat WSMV isolates have the identical aa substitution $(A \rightarrow G, 94 a a)$ with the $B 1$ non-crop isolates of this virus. Also, many aa substitutions are in the same motifs or near them (motif "№ 1" or TVESC at positions aa 100-104 and motif "№4" or

13 Mishchenko L. T., Dunich A. A., Mishchenko I. A., Petrenkova V. P., Mukha T. I. Monitoring of economically important wheat viruses under weather conditions change in Ukraine and investigation of seed transmission of Wheat streak mosaic virus. Bulgarian Journal of Agricultural Science. - 2018b. - 24(4). - P. 660-669. 
NE.RY.EDPVVFY at positions aa 135-147), which were previously found in the non-crop WSMV isolates of the B1 clade ${ }^{14}$.

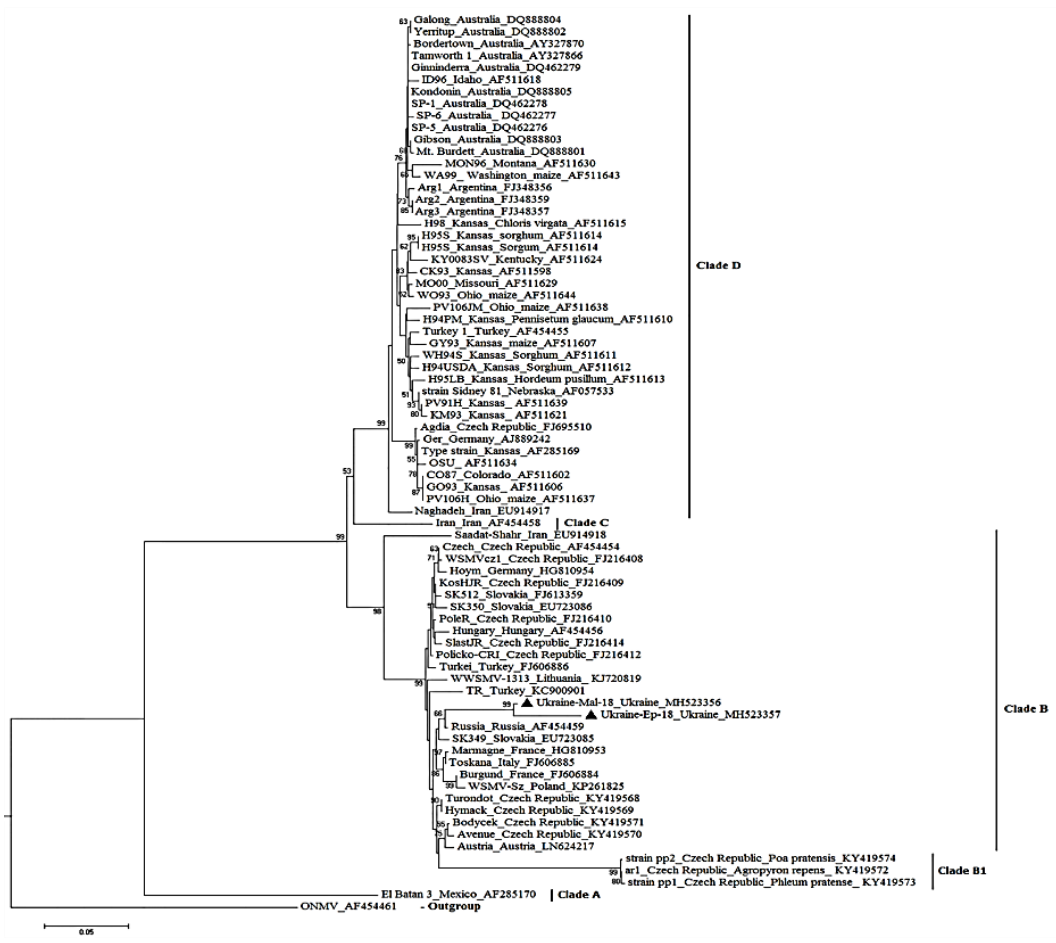

Fig. 6. Neighbor-Joining tree based on nucleotide sequences of 676 bp CP gene region of Ukrainian WSMV isolates and WSMV isolates from other countries. Jukes-Cantor model was performed. The scale bar shows the number of substitutions per base. Oat necrotic mottle virus, ONMV (Ac. No AF454461) used as an outgroup sequence. Ukrainian isolates are shown in triangles

More aa substitutions in the $C P$ sequence of the Ukraine-Ep-18 isolate were also revealed in the $\mathrm{N}$-terminal domain of the $C P$ gene, comparing with all the WSMV isolates taken to our study. It is known that tritimovirus $\mathrm{N}$-terminal domain of the $C P$ gene is less conserved

${ }^{14}$ Mishchenko L. T., Dunich A. A., Skrypkina I. Ya., Kozub N. O. Phylogenetic analysis of two Ukrainian isolates of Wheat streak mosaic virus. Biopolymers and Cell. 2019.Vol. 35. N 1. P 64-77. 
than the central and C-terminal regions ${ }^{15}$. In addition, it was found that major aa variations between wheat and grass WSMVs were in the $\mathrm{N}$-terminal region, namely in motifs 3 and $4^{16}$. However, in the wheat isolate Ukraine-Ep-18 we revealed aa substitutions in the motif 4, in contrast to other European wheat WSMVs. Prendeville et al. suggest that mutations in BYDV from wild grass populations can be connected with virulence factors and can act as positive fitness elements in wild plants ${ }^{17}$.

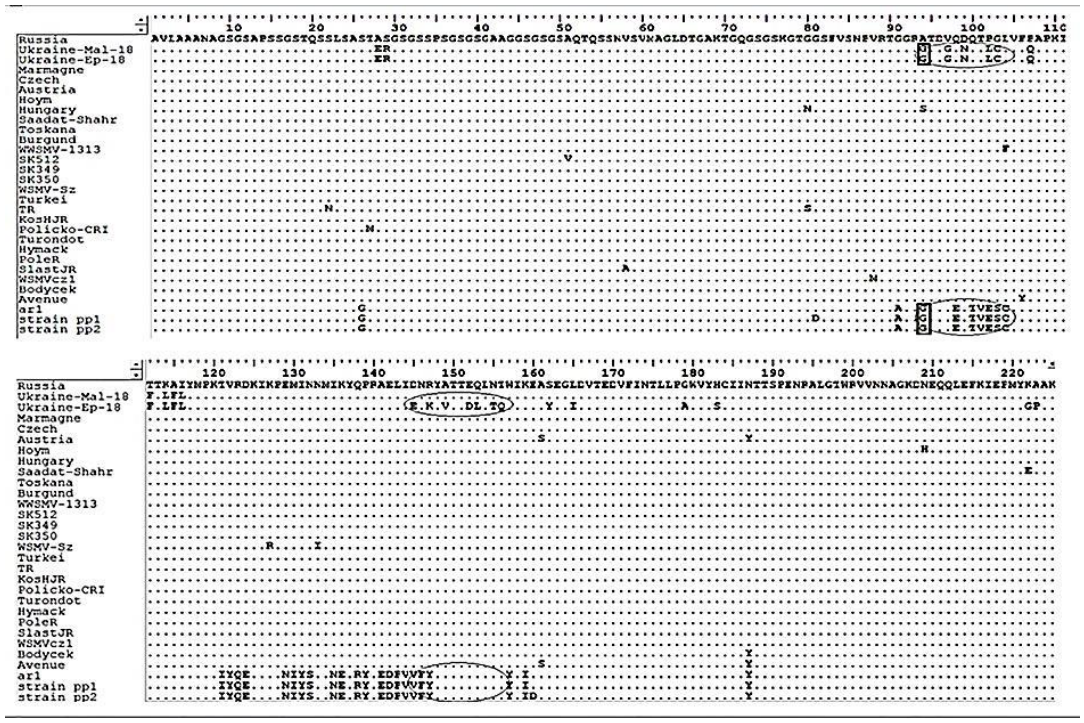

Fig. 7. Comparative analysis of amino acid sequences of Ukrainian WSMV isolates with the clade B and B1 strains. Identical aa variations among sequences are represented with boxes. Amino acid variations in the same regions are represented with circles. Numbers on top represent the deduced $\mathrm{CP}$ amino acid position. Only the differences are shown

15 Tatineni S., French R. The C-terminus of Wheat streak mosaic virus coat protein is involved in differential infection of wheat and maize through host specific long-distance transport. Mol Plant Microbe Interact. 2014. 27(2). P.150-62.

16 Singh K., Kundu J.K. Variations in Wheat streak mosaic virus coat protein sequence among crop and non-crop hosts. Crop Pasture Science. 2017. 68(4). P.328-336.

${ }^{17}$ Prendeville H.R., Tenhumberg B., Pilson D. Effects of virus on plant fecundity and population dynamics. New Phytol. 2014. 202(4). P.1346-56. 
Recently it has been revealed that the N-terminal region of tritimoviral $C P$ is involved in the host- and strain-specific long distance movement ${ }^{18}$. Perhaps, aa substitutions in this $C P$ region revealed by us for the isolate Ukraine-Ep-18 led to more severe symptoms, compared with the Ukraine-Mal-18 isolate but this requires additional research.

Our monitoring of crops revealed a significant impact of WSMV on wheat yield. Studies have shown a significant decrease in the productivity of virus-infected plants, namely: a decrease in the spike length (in 1.69-fold), and number of seeds per spike almost twice (1.92-fold) (Table 1, Fig. 8).

Table 1

\section{Productivity characteristics of the winter wheat var.} Julia under WMSV infection

\begin{tabular}{|c|c|c|c|c|c|c|}
\hline \multirow{2}{*}{ Sample } & \multicolumn{7}{|c|}{ Productivity parameter } \\
\cline { 2 - 7 } & $\begin{array}{c}\text { Plant } \\
\text { height, } \\
\mathbf{~ c m}\end{array}$ & $\begin{array}{c}\text { Spike } \\
\text { length, } \\
\text { cm }\end{array}$ & $\begin{array}{c}\text { Number of } \\
\text { spikelets } \\
\text { per spike, } \\
\text { pcs }\end{array}$ & $\begin{array}{c}\text { Number of } \\
\text { seeds per } \\
\text { spike }\end{array}$ & $\begin{array}{c}\text { Weight of } \\
\text { seeds per } \\
\text { spike, g }\end{array}$ & $\begin{array}{c}\text { Weight of } \\
\mathbf{1 0 0 0} \\
\text { grains, g }\end{array}$ \\
\hline $\begin{array}{c}\text { Healthy } \\
\text { plants }\end{array}$ & $103.1 \pm 4.8$ & $8.1 \pm 0.38$ & $16.1 \pm 0.78$ & $43.3 \pm 2.10$ & $2.24 \pm 0.062$ & $46.32 \pm .1 .54$ \\
\hline $\begin{array}{c}\text { WSMV- } \\
\text { infected } \\
\text { plants }\end{array}$ & $85.2 \pm 3.6^{*}$ & $4.8 \pm 0.22^{*}$ & $12.5 \pm 0.61 *$ & $22.5 \pm 1.02 * *$ & $0.55 \pm 0.024 * *$ & $31.3 \pm 1.12 *$ \\
\hline
\end{tabular}

$*$ differences are significant at $* P<0.01 ; * * P<0.001$.

Analysis of the yield structure revealed that wheat seeds and spikes from plants severely affected by WSMV look very small and thin compared to healthy ones (Fig. 8).
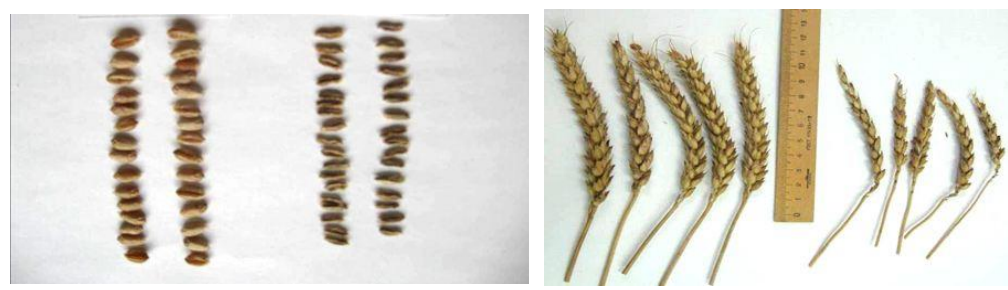

Fig. 8. Seeds and individual spikes of wheat var. Julia, Chernihiv region, 2019 $A$-form healthy plants; $B$-from WSMV-infected plants

18 Tatineni S., Van Winkle D.H., French R. The N-terminal region of wheat streak mosaic virus coat protein is a host- and strain-specific long-distance transport factor. J Virol. 2011. 85(4). P. 1718-31. 
Weight of seeds per spike from severely infected by WSMV plants var. Julia was reduced 4-fold and weight of 1000 grains decreased 1.5fold (Table 1). That is, plant productivity is mainly affected by the degree of seed set of the spike and the weight of 1000 grains, which are significantly reduced by viral infection.

WSMV-infected wheat plants formed short spikes. They were almost twice shorter than healthy ones. Grains from plants affected by the viral infection were small, thin and shriveled (Fig. 9).

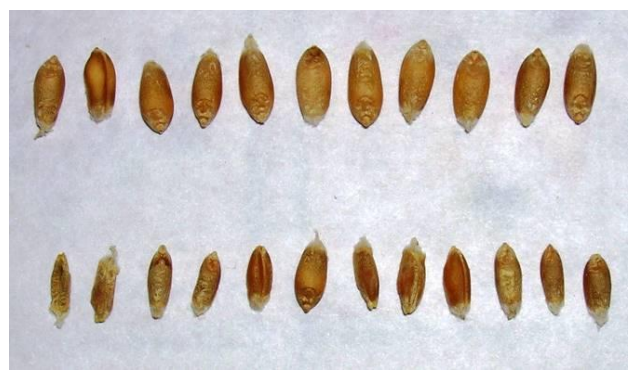

A

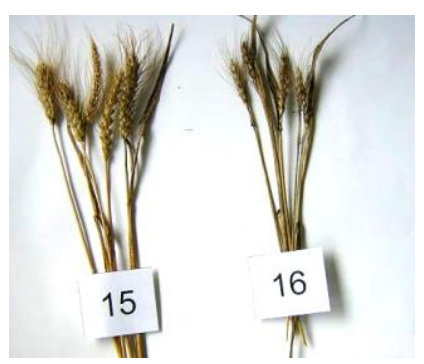

B

Fig. 9. Impact of WSMV on seed (A) and spike (B) formation of winter wheat var. Poliska 90

Seeds: on the top - from healthy plants, below - from WSMV-infected ones. Spikes: 15 - healthy plants, 16 -WSMV-infected

It was found that virus-infected wheat plants of the variety Smuhlianka differed significantly from healthy ones in such biometric indicators and yield structure as spike length, number of spikelets and seeds per spike, weight of seeds per spike (Table 2).

Table 2

\section{Productivity characteristics of the winter wheat var. Smuhlianka under WMSV infection}

\begin{tabular}{|c|c|c|c|c|}
\hline \multirow{2}{*}{ Sample } & \multicolumn{4}{|c|}{ Productivity parameter } \\
\cline { 2 - 5 } & Spike length, cm & $\begin{array}{c}\text { Number of } \\
\text { spikelets per } \\
\text { spike, pcs }\end{array}$ & $\begin{array}{c}\text { Number of seeds } \\
\text { per spike }\end{array}$ & $\begin{array}{c}\text { Weight of seeds } \\
\text { per spike, g }\end{array}$ \\
\hline $\begin{array}{c}\text { Healthy } \\
\text { plants }\end{array}$ & $7.7 \pm 0.36$ & $13.7 \pm 0.68$ & $33.3 \pm 1.61$ & $1.67 \pm 0.08$ \\
\hline $\begin{array}{c}\text { WSMV- } \\
\text { infected } \\
\text { plants }\end{array}$ & $4.4 \pm 0.21^{*}$ & $8.6 \pm 0.42^{*}$ & $14.1 \pm 0.70 * *$ & $0.48 \pm 0.02 * *$ \\
\hline
\end{tabular}

*differences are significant at $* P<0.01 ; * * P<0.001$. 
The number spikelets per spike from WSMV-infected plants were 1.6-fold smaller than that in healthy ones; the number of seeds per spike decreased 2.4-fold and their weight 3.5-fold (Table 2). The formation of thin grain in virus-infected plants is directly related to the violation of the photosynthesis processes, assimilation, in particular carbohydrate metabolism, and can be considered one of the diagnostic indicators of viral infection ${ }^{19}$.

Our studies of the ultrastructural organization of cells from virusinfected plants have shown marked changes in many structural components of the cell. Thus, the matrix of the infected cell had a low electron density; the inner membrane system was degraded. In mitochondria, the matrix and cristae began to disappear (Fig. 10,11).

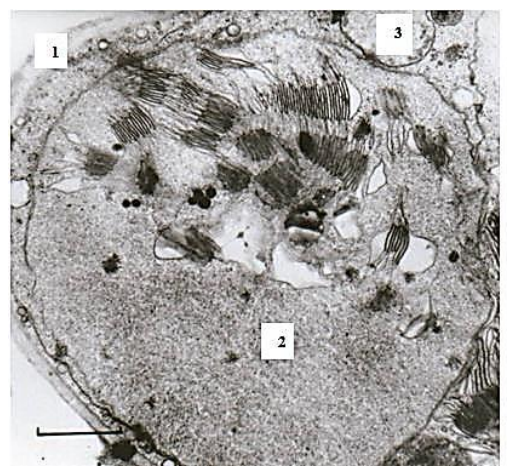

A

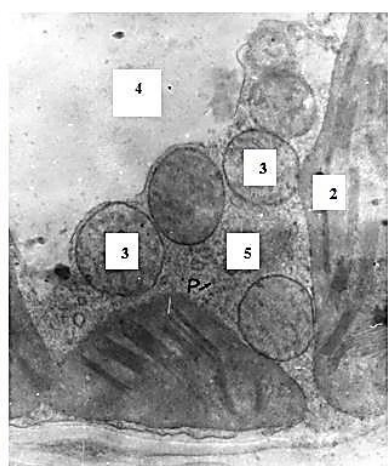

B

Fig. 10. Ultrastructure of wheat mesophyll cells:

A - WSMV-infected; B - healthy

1 - cell membrane; 2 - chloroplast, 3 - mitochondria, 4 - vacuole; 5 - cytoplasm. Magnification $\times 25000$

In chloroplasts, the number of thylakoids in the granum decreased, destruction of the lamellar system was observed, and the connection of its stroma with thylakoids was partially interrupted. The intermembrane space of the lamellae had ampullary bulges. The electron density of the matrix was very low. In addition, osmophilic globules and starch were present in the chloroplasts of infected cells.

${ }^{19}$ Mishchenko L.T., Reshetnyk G.V., Torop V.V. Comprehensive diagnostics of symptoms of "purple leaves" of winter wheat. Bulletin of Agricultural Science. 2010. № 4. P. 27-30. (in Ukrainian) 


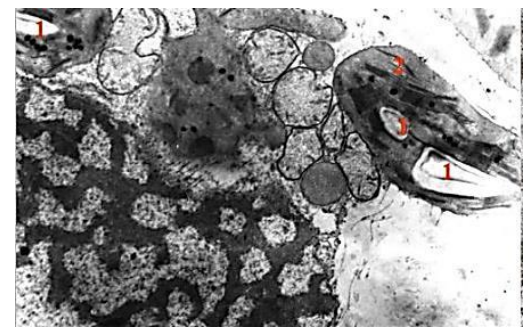

A

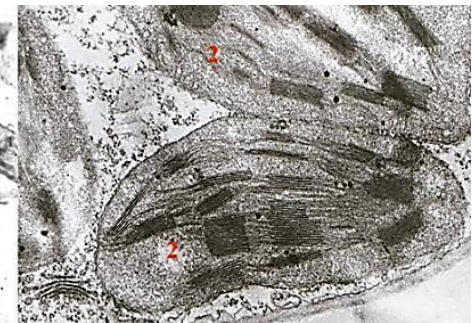

B

Fig. 11. Ultrastructure of mesophyll cells of wheat пшениці var. Donskaya polukarlikovaya

A-WSMV-infected; B - healthy; On the photos: 1 -starch grains, 2 - chloroplast

\section{Fungal diseases}

In 2019, fungal infections predominated, they were found on 22 wheat varieties. Among the fungal pathogens on wheat, stem and leaf rust (pathogens Puccinia graminis Rers. and Puccinia recondita f. sp. tritici) predominated, which were found in the Kyiv region on 7 wheat varieties. The degree of damage was from 5 to $50 \%$ depending on the variety (Fig. 12).

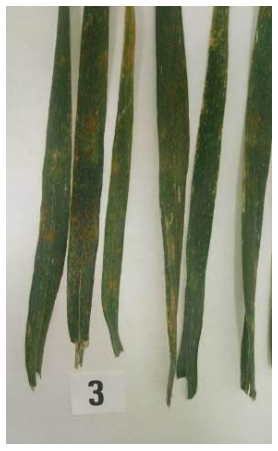

A

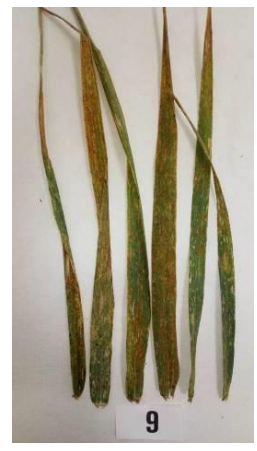

$\mathrm{B}$

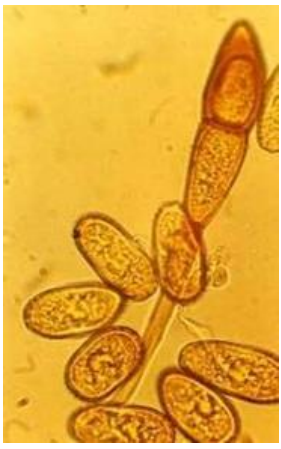

C

Fig. 12. Symptoms caused by Puccinia recondita f. sp. tritici on wheat var.

Bozhena, July 2019, Kyiv region (A $-1^{\text {st }}$ of July, degree of damage $10 \%$;

B $-7^{\text {th }}$ of July, degree of damage over $50 \%$ ) and fungal spores (C)

Another common pathogen, Septoria tritici Rob et Desm, was found in 2019 in 4 regions: on 4 wheat varieties and one winter barley variety in the Khmelnytsky region; on 3 wheat varieties in the Kyiv region; one 
variety in the Chernihiv and Poltava region regions; and 12 varieties in 2020 in the Odessa region.

Amongst the less frequently observed infections were combination of Erysiphe graminis DC and Septoria tritici Rob et Desm on a winter barley variety Gladiator in the Khmelnitsky region; on wheat var. Elegia Myronivska in the Kyiv region and on 7 wheat varieties in 2020 in Odessa region (Fig. 13).

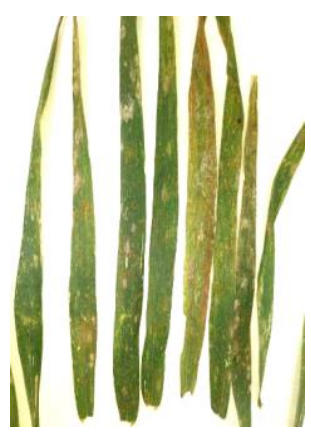

A

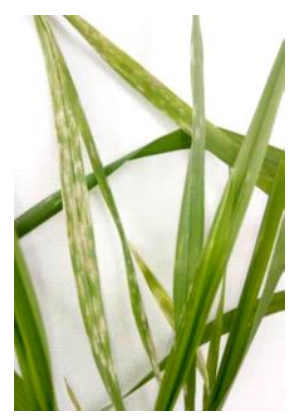

B

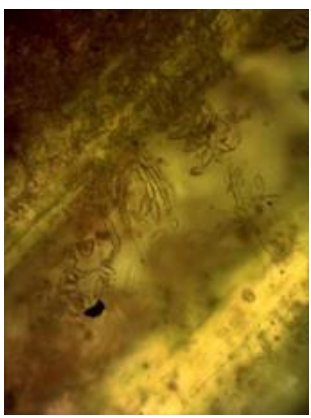

$\mathrm{C}$

Fig. 13. Symptoms caused by Erysiphe graminis DC on wheat leaves (A, B) and fungal conidia (C): A - var. Elegia, Kyiv region, 2019; B - var. Garanta, Odessa region, 2020

Pyrenophora tritici-repentis (Died.) Drechsler) was detected in Poltava region in 2019 (Fig. 14).

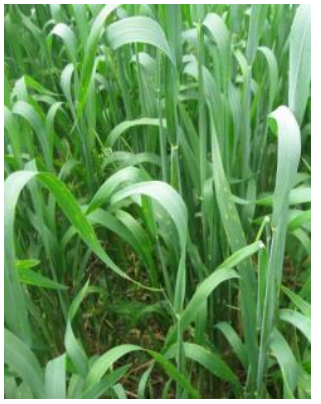

A

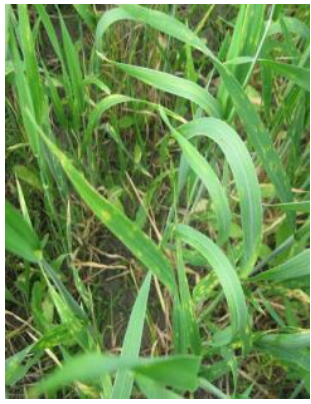

B

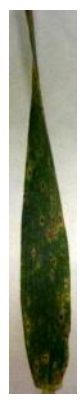

$\mathrm{C}$

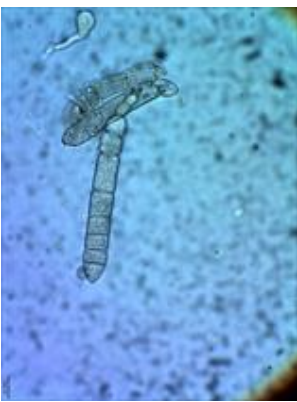

D

Fig. 14. Symptoms (A-C) caused by Pyrenophora tritici-repentis (Died.) Drechsler on wheat var. Bogdana, Poltava region and fungal conidia (D): A - May, 2019, weak infection; B, C - July 2019, severe infection 
Snow mold (pathogen Fusarium nivale Ces) was found in 2019 in three regions of Ukraine: Poltava, Kyiv and Khmelnitsky on three wheat varieties.

The results of the studies aimed to determine the effect of the fungi Fusarium nivale and Pyrenophora tritici-repentis on wheat yield are shown in tables 3 and 4.

Table 3

Impact of Fusarium nivale Ces on productivity of wheat var. Kosach, 2019

\begin{tabular}{|c|c|c|c|c|c|c|}
\hline \multirow{2}{*}{ Sample } & \multicolumn{6}{|c|}{ Productivity parameter } \\
\cline { 2 - 7 } & $\begin{array}{c}\text { Plant } \\
\text { height, } \\
\text { cm }\end{array}$ & $\begin{array}{c}\text { Spike } \\
\text { length, } \\
\text { cm }\end{array}$ & $\begin{array}{c}\text { Number of } \\
\text { spikelets } \\
\text { per spike, } \\
\text { pcs }\end{array}$ & $\begin{array}{c}\text { Number of } \\
\text { seeds per } \\
\text { spike, pcs }\end{array}$ & $\begin{array}{c}\text { Weight of } \\
\text { seeds per } \\
\text { spike, g }\end{array}$ & $\begin{array}{c}\text { Weight of } \\
\text { 1000 grains, }\end{array}$ \\
\hline $\begin{array}{c}\text { Healthy } \\
\text { plants }\end{array}$ & $98.2 \pm 4.5$ & $7,8 \pm 0.39$ & $14.1 \pm 0.62$ & $33.2 \pm 1.65$ & $0.91 \pm 0.04$ & $35.6 \pm 1.48$ \\
\hline $\begin{array}{c}\text { Infected } \\
\text { by } \\
\text { F. nivale }\end{array}$ & $75.1 \pm 3.7^{*}$ & $4,2 \pm 0.20^{*}$ & $7.6 \pm 0.36^{*}$ & $14.3 \pm 0.69 * *$ & $0.46 \pm 0.022^{* *}$ & $26.9 \pm 1.32^{* *}$ \\
\hline
\end{tabular}

*differences are significant at $* P<0.01 ; * * P<0.001$.

Studies have shown that the snow mold fungus (Fusarium nivale Ces) is a serious plant disease, which reduces the productivity of wheat plants. Spike length decreases by 1.85 times, the number of seeds and weight of seeds per spike reduced by 1.6 and 2 times, respectively. Weight of 1000 grains in wheat infected by $F$. nivale decreased by $25 \%$ (Table 3 ). The reduction in yield is due to the reduction in the spike length and the number of seeds in it, which leads to a decrease in the weight of seeds per spike. There is a low number of seeds per spike because of its short length. Due to modern new varieties, wheat plants after the defeat of this fungus have the ability to grow up, but these plants are somewhat weaker and lag in stages of development. The old varieties had not grown much after the defeat by Fusarium nivale Ces, so the damaged fields were sown with spring varieties and the grain was already considered fodder, not marketable. This has significantly worsened the food security of our country.

Studies have shown that Pyrenophora tritici-repentis also reduces the productivity of wheat plants, which manifested mainly in the reduced number of seeds per spike and weight of 1000 grains, which decreased under fungal infection by 1.32 and 1.24 times, respectively (Table 4, Fig. 15). 
Table 4

Impact of Pyrenophora tritici-repentis on productivity of wheat var.

Bogdana, 2019

\begin{tabular}{|c|c|c|c|c|c|c|}
\hline \multirow{2}{*}{ Sample } & \multicolumn{6}{|c|}{ Productivity parameter } \\
\cline { 2 - 7 } & $\begin{array}{c}\text { Plant } \\
\text { height, } \\
\text { cm }\end{array}$ & $\begin{array}{c}\text { Spike } \\
\text { length, } \\
\text { cm }\end{array}$ & $\begin{array}{c}\text { Number of } \\
\text { spikelets } \\
\text { per spike, } \\
\text { pcs }\end{array}$ & $\begin{array}{c}\text { Number of } \\
\text { seeds per } \\
\text { spike }\end{array}$ & $\begin{array}{c}\text { Weight of } \\
\text { seeds per } \\
\text { spike, g }\end{array}$ & $\begin{array}{c}\text { Weight of } \\
\text { 1000 grains, } \\
\text { g }\end{array}$ \\
\hline $\begin{array}{c}\text { Healthy } \\
\text { plants }\end{array}$ & $88,2 \pm 3.9$ & $7.4 \pm 0.36$ & $15.6 \pm 0.77$ & $25.7 \pm 1.22$ & $1.21 \pm 0.06$ & $42.7 \pm 1.51$ \\
\hline $\begin{array}{c}\text { Infected by } \\
\text { Pyrenophora }\end{array}$ & $77,3 \pm 3.1 *$ & $5.5 \pm 0.26^{*}$ & $12.3 \pm 0.61 *$ & $19.2 \pm 0.91 *$ & $0.93 \pm 0.04 * *$ & $34.5 \pm 1.28 * *$ \\
\hline
\end{tabular}

$*$ differences are significant at $* P<0.01 ; * * P<0.001$.

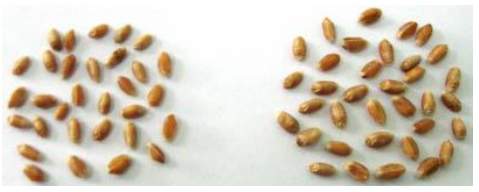

A

B

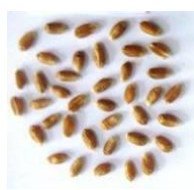

$\mathrm{C}$

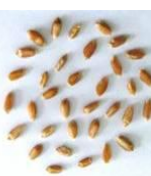

$\mathrm{D}$

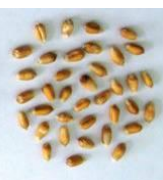

E

Fig. 15. Seed collected from infected wheat plants: A, B - Pyrenophora triticirepentis (A - infected, B-healthy); C-E - Fusarium nivale (C - healthy, D - greatly affected, E - medium affected plants)

The results of the study of the effects of fungal and viral infections showed that in 2019, a very dry year, wheat yields decreased more due to viral infections compared to fungal. Among the fungal diseases that we found in farms in Poltava region in significant quantities (20-30\%), more harmful was the snow mold Fusarium nivale, compared with pyrenophora (Pyrenophora tritici-repentis), which has recently appeared in our country.

\section{CONCLUSIONS}

Thus, during many years of research we have taken field samples of different wheat varieties from different regions of Ukraine (more than 80 varieties) with symptoms of viral and fungal infections. It was established that in 2011-2017 BYDV and WSMV were replacing each other from year to year, and cases of co-infection of these viruses were not recorded. Such periodic variability of viruses (WSMV or BYDV) is closely related to agroclimatic changes (air temperature, rainfall, temperature at soil surface, soil temperature on tillering node depth of winter crops and perennial grasses, and soil freezing depth in winter) that affect their host plants and vectors throughout the year and plants 
reservoirs in the winter, and also cause symptoms similar to viral infection. Climatic conditions also affect phytopathogens of fungal etiology. It was found that in 2019, on wheat fields fungal infections predominated. A total of 8 species of fungal pathogens were detected in wheat crops. The most common of them were stem and leaf rust, septoria, pyrenophora and snow mold (Puccinia graminis Rers., Puccinia recondita f. sp. tritici та Septoria tritici Rob et Desm, Pyrenophora tritici-repentis (Died.) Drechsler, Fusarium nivale Ces). In the period of 2018-2020, among the viral infections, the wheat streak mosaic virus was detected. Phylogenetic studies of Ukrainian WSMV isolates have been carried out, and viral sequences have been deposited into the NCBI GenBank. It has been established that they have unique amino acid substitutions, and WSMV isolates of 2018 have 6-10 times more such non-synonymous mutations in the sequence of the capsid protein gene than other foreign WSMVs, which indicates high divergence of Ukrainian isolates. Such changes at the genetic level can lead to changes in biological properties, including increased virulence of isolates, speed and efficiency of vector transmission, harmfulness to plants etc. It was found that WSMV infection significantly (4-fold) reduces grain productivity of winter wheat compared to healthy plants. Snow mold fungi reduce the productivity of wheat spikes by half, and pyrenophora decreases it by 1.3 times. The results of the study of effects of fungal and viral infections showed that in 2019, a very dry year with a large amount of vector insects, wheat yields decreased more due to viral infections compared to fungal.

\section{SUMMARY}

Electron microscopic, serological, molecular, genetic and phylogenetic studies have shown that the most common virus in wheat in Ukraine is wheat streak mosaic virus (WSMV). Among the wheat fungi most common in recent years are the pathogens Puccinia graminis Rers., Puccinia recondita f. sp. tritici Ta Septoria tritici Rob et Desm, Pyrenophora tritici-repentis (Died.) Drechsler, Fusarium nivale Ces. These pathogens cause significant economic losses to the wheat crop, reducing its grain productivity. Such harmfulness may be due to the presence of mutations in pathogen sequences, such as unique amino acid substitutions in sequences of the Ukrainian WSMVs and higher divergence of some of them compared to isolates of this virus from other countries. Our results of more than 30 years of research on wheat plant pathogens in Ukraine and their significant harmful effects on yields indicate the need for frequent monitoring of pathogens and study of their 
biological and molecular characteristics to develop adequate measures to protect and minimize wheat yield losses.

\section{References}

1. Fones H.N., Bebber D.P., Chaloner T.M. et al. Threats to global food security from emerging fungal and oomycete crop pathogens. Nat Food. 2020. 1. P. 332-342. https://doi.org/10.1038/s43016-020-0075-0

2. Jones R.A.C. Global plant virus disease pandemics and epidemics. Plants. 2021. 10(2). 233; https://doi.org/10.3390/plants10020233

3. Priyadi M., Upadhyay P. Emerging plant diseases under changing climate scenario. In: Singh K.P., Jahagirdar S., Sarma B.K. (eds) Emerging trends in plant pathology. Springer, Singapore. 2021. P. 19-31. https://doi.org/10.1007/978-981-15-6275-4_2

4. Strange R.N., Scott P.R. Plant disease: a threat to global food security. Annual Review of Phytopathology. 2005. 43(3). P. 83-116. doi: 10.1146/annurev.phyto.43.113004.133839

5. Singh K., Wegulo S.N., Skoracka A., Kundu J.K. Wheat streak mosaic virus: A century old virus with rising importance worldwide. Mol. Plant Pathol. - 2018. - 19. - P. 2193-2206. https://doi.org/10.1111/mpp.12683

6. Mishchenko L.T. Viral diseases of winter wheat. K.: Phytosociocenter. - 2009. 352 p. (in Ukrainian)

7. Mishchenko L.T., Dunich A.A., Budzanivska I.G., Mishchenko I.A. Viral infections of winter wheat and soybean and their influence on crop yield under climate change conditions. Bulletin of Taras Shevchenko National University of Kyiv. Series: Biology. 2018a. Vol. 75(1). P. 11-21. (in Ukrainian)

8. Namara L.M., Gauthier K., Walsh L., Thébaud G., Gaffney M., Jacquot E. Management of yellow dwarf disease in Europe in a postneonicotinoid agriculture. Pest Management Science. 2020. 76(7). P. 2276-2285. https://doi.org/10.1002/ps.5835

9. Nancarrow N., Aftab M., Hollaway G., Rodoni B., Trębicki P. Yield losses caused by barley yellow dwarf virus-PAV infection in wheat and barley: a three-year field study in South-Eastern Australia. Microorganisms. 2021. 3(9). P. 645. https://doi.org/10.3390/microorganisms 9030645

10. Miedaner, T., Juroszek, P. Climate change will influence disease resistance breeding in wheat in Northwestern Europe. Theor Appl Genet. 2021. https://doi.org/10.1007/s00122-021-03807-0

11. Różewicz M., Wyzińska M., Grabiński J. The most important fungal diseases of cereals-problems and possible solutions. Agronomy. 2021. 11(4). P.714; https://doi.org/10.3390/agronomy 11040714 
12.Jeong J., Ju H., Noh J. A review of detection methods for the plant viruses. Res. Plant Dis. 2014. 20(3). P. 173-181.

13. Mishchenko L.T., Dunich A.A., Mishchenko I.A., Petrenkova V.P., Mukha T.I. Monitoring of economically important wheat viruses under weather conditions change in Ukraine and investigation of seed transmission of Wheat streak mosaic virus. Bulgarian Journal of Agricultural Science. 2018b. 24(4). P. 660-669.

14. Mishchenko L.T., Dunich A.A., Skrypkina I.Ya., Kozub N.O. Phylogenetic analysis of two Ukrainian isolates of Wheat streak mosaic virus. Biopolymers and Cell. 2019. Vol. 35. N 1. P 64-77.

15. Tatineni S., French R. The C-terminus of Wheat streak mosaic virus coat protein is involved in differential infection of wheat and maize through host specific long-distance transport. Mol Plant Microbe Interact. 2014. 27(2). P.150-62.

16.Singh K., Kundu J.K. Variations in Wheat streak mosaic virus coat protein sequence among crop and non-crop hosts. Crop Pasture Science. 2017. 68(4). P.328-336.

17.Prendeville H.R., Tenhumberg B., Pilson D. Effects of virus on plant fecundity and population dynamics. New Phytol. 2014. 202(4). P.1346-56.

18. Tatineni S., Van Winkle D.H., French R. The N-terminal region of wheat streak mosaic virus coat protein is a host- and strain-specific longdistance transport factor. J Virol. 2011. 85(4). P. 1718-31.

19. Mishchenko L.T., Reshetnyk G.V., Torop V.V. Comprehensive diagnostics of symptoms of "purple leaves" of winter wheat. Bulletin of Agricultural Science. 2010. № 4. P. 27-30. (in Ukrainian)

\section{Information about the authors: Mishchenko Lidiya Trohymivna, Doctor of Biological Sciences, Professor, Professor} Education and Scientific Center "Institute of Biology and Medicine" of Taras Shevchenko National University of Kyiv 64/13, Volodymyrska str., Kyiv, 01601, Ukraine

\section{Dunich Alina Anatoliivna, \\ PhD of Biological Sciences,}

Research Fellow at the Virology Department Education and Scientific Center "Institute of Biology and Medicine" of Taras Shevchenko National University of Kyiv 64/13, Volodymyrska str., Kyiv, 01601, Ukraine 